\title{
Erratum to: Kinky circumflex grafts: The left appendage flip maneuver. Thorac Cardiovasc Surg 2013;61:687-690
}

Ivor F. Galvin ${ }^{1}$ Nur Azri Bin Haji Mohd Yasin ${ }^{1} \quad$ Pankaj Saxena ${ }^{1}$

${ }^{1}$ Dunedin Hospital and the University of Otago, Dunedin, New

Address for correspondence Ivor F. Galvin, FRACS, Department of Zealand Cardiothoracic Surgery, Dunedin Hospital, Great King Street, Dunedin Thorac Cardiovasc Surg 2013;61:e3. 9054, New Zealand (e-mail: ivorg@xtra.co.nz).

\section{ERRATUM}

It has been brought to the Publisher's attention that the author name "Nur Azri Bin Haji Mohd Yasin" is not appearing correctly in the above mentioned article, published eFirst on August 6, 2013. DOI of the original article is DOI: $10.1055 / \mathrm{s}-0033-1351117$.

The name should be read as "Haji Mohd Yasin, Nur A.B." in place of "Mohd Yasin, Nur A.B. Hazi." 